\title{
RESEARCHING PROFESSIONAL BIOGRAPHIES OF EDUCATIONAL PROFESSIONALS IN NEW DARK TIMES
}

DOI:

10.1080/00071005.2019.1673879

10.1080/00071005.2019.1673879

\section{Document Version}

Accepted author manuscript

Link to publication record in Manchester Research Explorer

\section{Citation for published version (APA):}

Hughes, B., Gunter, H., \& Courtney, S. (2019). RESEARCHING PROFESSIONAL BIOGRAPHIES OF EDUCATIONNAL PROFESSIONALS IN NEW DARK TIMES. British Journal of Educational Studies, 68(3), 275-293. https://doi.org/10.1080/00071005.2019.1673879, https://doi.org/10.1080/00071005.2019.1673879

\section{Published in:}

British Journal of Educational Studies

\section{Citing this paper}

Please note that where the full-text provided on Manchester Research Explorer is the Author Accepted Manuscript or Proof version this may differ from the final Published version. If citing, it is advised that you check and use the publisher's definitive version.

\section{General rights}

Copyright and moral rights for the publications made accessible in the Research Explorer are retained by the authors and/or other copyright owners and it is a condition of accessing publications that users recognise and abide by the legal requirements associated with these rights.

\section{Takedown policy}

If you believe that this document breaches copyright please refer to the University of Manchester's Takedown Procedures [http://man.ac.uk/04Y6Bo] or contact uml.scholarlycommunications@manchester.ac.uk providing relevant details, so we can investigate your claim.

\section{OPEN ACCESS}




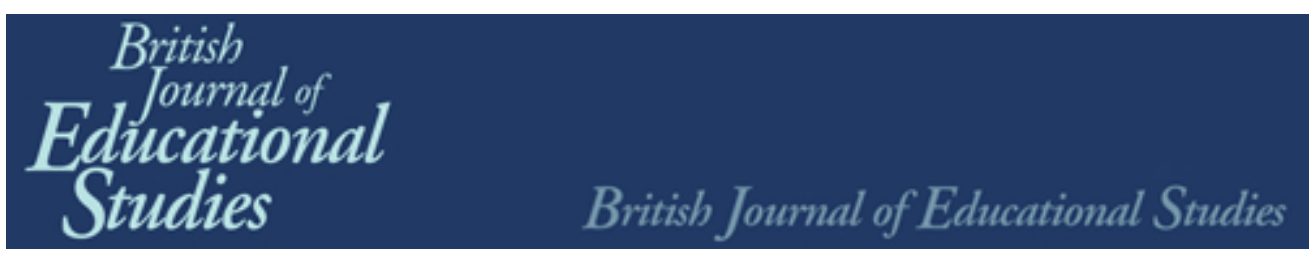

\section{Researching professional biographies of educational professionals in new dark times}

\begin{tabular}{|r|l|}
\hline Journal: & British Journal of Educational Studies \\
\hline Manuscript ID & BJES-05-19-0080-RI.R1 \\
\hline Keywords: & Arendt, multi academy trusts, CEO, privatiseation, school leadership \\
\hline & $\begin{array}{l}\text { Education reform under the modernisation agenda both in England and } \\
\text { internationally has signified the restoration of the 'private' and the } \\
\text { decline of 'public' education. Deploying Arendtian thinking on } \\
\text { assimilation and identity, we argue that these ongoing reforms are } \\
\text { indeed dark times for education professionals. We examine what 'new } \\
\text { dark times' mean for those in leader roles in schools and organisations } \\
\text { that are contracted to deliver, such as a multi academy trust (MAT). } \\
\text { Based on a year-long research project which focussed on a multi } \\
\text { academy trust in England, the article reports on the position and practice } \\
\text { of the CEO, KT Edwards in these new dark times. We conclude that the } \\
\text { emerging CEO position is being defined through individual positioning, a } \\
\text { repudiation of the past and the assimilation into the private realm of } \\
\text { non-education dark times. }\end{array}$ \\
\hline & \\
\hline
\end{tabular}

\section{SCHOLARONE \\ Manuscripts}




\title{
Researching professional biographies of educational professionals in new dark times
}

\begin{abstract}
Education reform under the modernisation agenda both in England and internationally has signified the restoration of the 'private' and the decline of 'public' education. Deploying Arendtian thinking on assimilation and identity, we argue that these ongoing reforms are indeed dark times for education professionals. We examine what 'new dark times' mean for those in leader roles in schools and organisations that are contracted to deliver, such as a multi- academy trust (MAT). Based on a year-long research project which focussed on a multi academy trust in England, the article reports on the position and practice of the CEO, KT Edwards in these new dark times. We conclude that the emerging CEO position is being defined through individual positioning, a repudiation of the past and the assimilation into the private realm of non-education dark times.
\end{abstract}

Key words: Arendt, multi-academy trusts, CEO, privatisation, school leadership

\section{Introduction}

The modernisation of public services education in western-style democracies is premised on the restoration of the private as the legitimate and liberating site for decision-making and choice (Gunter, 2018a). Private consortia provide school places in the form of charters in the USA, free schools in Sweden, and academies in England, and determine the curriculum, and the composition of the workforce. Contemporary histories of such modernisation in England display potential along with a vitality and optimism for professional practices (e.g. Astle and Ryan, 2008), where it seems that such reforms have 'switched on' the light for innovation. We examine such claims by examining the professional biography and practices of a Chief Executive Officer (CEO) of a MultiAcademy Trust (MAT) in England where we report on data from the Leadership of the Lawrence Trust Project (LLTP). Specifically, we argue that reforms have 'dimmed' and are on a trajectory to actually 'switching off' the light of public services education. Following Newman and Clarke (2009) we are concerned with how within such a trend 
"publicness is constituted" ( $\mathrm{p}$ 2) through the emerging advantages of private decisions, locations and exchange networks.

Like Hannah Arendt (1993), we use the motif of 'dark times' from Brecht's poem To Those Born After where he describes the rupture with the past:

Truly I live in dark times!

...What times are these, in which

A conversation about trees is almost a crime

For in so doing we maintain our silence about so much wrongdoing? (Brecht, 2019, p. 734).

Whilst acknowledging that 'history knows many periods of dark times' (Arendt, 1993, p. 11) and researchers are mapping this emerging obscurity in education (e.g. Au and Ferrare, 2015; Gunter, 2018b; Ravitch, 2014), we illuminate new dark times through a case analysis from the LLTP. A CEO of a MAT is an emerging new role, where MATs operate independently of local authorities and are centrally funded by the government using public resources. Our data show that what is distinctively new about current dark times is how decision-making in the name of the public has been rendered 'darkly' private. Following Newman and Clarke $(2009$, p2) regarding how and why public services education was politicised within public institutions, staffed by professionals with a "public service ethos", and hence "served" and was "accountable" to the public, the notion and reality of publicness is now being depoliticised in order to legitimise private interests, arenas and advantages. Depoliticisation in the provision of school places is premised on a return to the privileged privacy of individualised beliefs, decisions and activity within a concealed world of the family enabled by philanthropy, corporatisation, and faith groups. Educational professionals who are already working in the system are required to forget, and hence adopt the espoused values, purposes and practices from the 
modernised system or render themselves disposable (Courtney and Gunter 2015; Gunter 2018b). We recognise that little independent research explores the emerging phenomenon of the CEO as a dynamic lived experience, where those who take up such a post may have a professional biography that is located in the public politicised system that predates the reforms. The data from the LLTP gives us the opportunity to examine ethnographically the professional biography of such a CEO, how he entered a public system and is now working hard as a moderniser. Our approach is novel because for the first time we examine the CEO role and the actual role incumbent through utilising Arendtian scholarship of the 'parvenu' as yearning for assimilation juxtaposed with the 'pariah' as outsider. Our contribution is to provide new evidence and conceptualisations of professional practice that identify how and why the case of KT Edwards illustrates a parvenu in waiting while in the public system, and how his current adaptation as a CEO uses his assumed public services pariah experience to enable the modernisation process.

\section{Educational professionals in new dark times}

Educational professionals who work in public-services education in England are informed they are now working in the 'light' where neoliberal and neoconservative 'light shiners' have not only exposed the 'red tape' of bureaucracy and the 'provider capture' of professionals but have enabled opportunities afforded by the domination of private interests and the privatisation of educational services (e.g. Guggenheim, 2010).

In reality, darkness has descended. Such darkness is both structural and cultural where reforms have been introduced across nation states that disassemble and halt universal access to a free-at-the-point-of-delivery school education based on a broad and balanced curriculum, with teaching and learning provided by graduate professionals. Those who entered the education profession before waves of intensive reforms are 
required to forget: they have been re-professionalised through new branded identities (as a business, philanthropic charity or faith community) and are trained as leaders, who lead the vision and exercise leadership through securing compliance to the head-office 'thereis-no-alternative' vision. Forgetting public professional histories and research is premised on the logic of evidence-informed policy and practice, but it constitutes a form of darkness because much policy is premised on lies (Gorski and Zenkov, 2014). Normative and ideological claims are made about the purposes of the school and the school as an organisation, whereby modernising narratives of leadership, performance and responsiveness to consumer needs are seductive, and render alternative ideas, language and practice as oppositional to effectively meeting children's 'needs'. This darkness can be understood through what Appadurai (2017) identifies as 'democracy fatigue' (p.1), whereby the 'will of the people' is espoused to fabricate economic control, promote hostile environments, and pursue and/or condone criminality, and is based on 'the fabricated world of political truth created by mass media' (Benhabib 1996, p. 14). It seems that people are 'fed up with democracy itself' (Appadurai 2017, p. 7) and in voting for anti-democratic leaders, they are in effect voting for 'exit' (p. 7) and consenting to policies that threaten their interests.

Darkness generates performative isolation. In Arendtian (1958) terms, teachers labour over data production, work to evaluate that data, but rarely take action in the public realm to consider and understand the purposes of this individualised calculation. Decision-making has shifted from publicly accountable institutions and elected officials to depoliticised private arenas, and those involved use privacy to operate in an espoused public interest. Such decision-making is focused on the policy-enabled disposability of children, families and staff who do not fit. In England, for example, a catastrophe is unfolding: reports of corruption (e.g. Beckett, 2007); taxpayer-funded corporate-level 
salaries (e.g. Mansell, 2018); school closures leaving children and parents without a school place (e.g. McInerney, 2018); children being removed from the roll due to their predicted negative impact on school-performance data (e.g. Weale, 2018); and educational professionals facing non-renewal of their contracts owing to non-compliance (e.g. Courtney and Gunter, 2015). Evidence shows that over time, education professionals in England have taken a range of positions:

- Accepting: headteachers may be ambivalent but they are prepared to work within the new system (Goddard, 2014);

- Leading: headteachers who are fully compliant and who seek to lead and develop the reforms (Astle and Ryan, 2008);

- Complaining: headteachers have questioned vociferously the logic and challenges of certain reforms (Arrowsmith, 2001);

- Resisting: headteachers have sought to re-interpret reforms and be noncompliant with certain changes (Winkley, 2002);

- Refusing: educational professionals who may seek promotion but not to the top role of headteacher (Stanford, 2007);

- Leaving: headteachers have left rather than enact the new changes (Turner, 2018).

Historical evidence shows that headteachers can and do position differently from each other in regard to proposed and unfolding reforms, and in ways that can be contradictory but survivable (see Grace, 1995; Gunter and Forrester, 2010; Gunter and Hall, 2013). However, in new dark times, those who head up education services such as MATs and schools in England, are required to reject democratic oversight, and to demonstrate enthusiasm for leading and leadership that is less about the curriculum, pedagogy and assessment for all children as educable and is more about protecting and enabling the 
private interests that underpin brand integrity by excluding children from taking up a school place (e.g. faith observance; IQ testing; boy-girl identification). In reality, this means that major social ruptures such as gun and knife crime are responded to through securitisation of the school (e.g. scanners, expulsions); major economic ruptures such as the closure of a local employer is responded to through aspirational social mobility (e.g. segregated schools where the non-achieving poor are kept away from talented, achieving children); and major cultural ruptures such as population movements are responded to through assimilation (e.g. segregated schools that embrace children who benefit the league-table position) (see Gunter 2018b; Saltman and Gabbard 2003). This unfolds in the everydayness of school life through approved-of behaviour discourse for children (e.g. silent corridors, eyes forward in classrooms and mobile-phone bans) and teachers (e.g. compliant performance followers); the removal of sites of dissent from meetings through to schools built without staffrooms; combined with the 'celebritisation' of headteachers as chief executives who are feted by government. While there are emerging accounts of new forms of educational provision and professional positioning as 'school leaders' (e.g. Kulz, 2017; Salokangas and Ainscow, 2018), there has been little examination of position-taking by those inhabiting the CEO role in MATs in these new dark times. Our position is that the field of educational leadership does not currently access the intellectual resources necessary to bring meaning and explanation to this new role in new dark times, and so we argue that Arendtian scholarship provides the required thinking tools.

\section{Researching educational professionals in new dark times}

Accounts by professionals about doing the headteacher role in England are replete with events, reflections and legacy assessments about what the job actually is and what it 
means for the person doing the job (e.g. Clark, 1998; Daniels, 2011; Thomson, 2009). While there are some ethnographic-style projects and reflexive discussions (e.g. Gewirtz, 2002; Ribbins and Sherratt, 1999; Southworth, 1995), the main approach to researching into professional practice has tended to focus on researcher-practitioner interviews. This form of data generation enables educational professionals as respondents to compose and emplot post hoc narratives about their professional biographies through independently designed projects (e.g. Ribbins, 1997) with a range of theorising about practice (e.g. Sugrue, 2005). These approaches provide understandings about purposes and practices in changing times, but the underlying assumption is that the settlement regarding the legitimacy of public-services education is intact. New dark times are dismantling publicservices education based on the disposability of people, and so there is a need to think about methodologies and methods that capture the realities of positioning by those who entered a predominantly public system, but who are now working in a privatised system. We intend following up on Arendt's contention that 'even in the darkest of times we have the right to expect some illumination' (Arendt, 1993, p. ix), and we intend doing this through innovative empirical and conceptual analysis.

Our empirical approach is based on a year-long ethnographic study of one MAT CEO in England, KT Edwards. A headteacher for over ten years, the Lawrence Trust was formed in 2012 with Edwards becoming its CEO in 2014 comprising eight schools covering a wide geographical region encompassing three LAs. The Trust employs over 1000 staff and educates over 6000 pupils. The study followed established ethnographic traditions of case studies of single schools (e.g. Kulz, 2017) and those of individual head teachers (or Principals) (e.g. Southworth, 1995; Wolcott, 1973). We sought to investigate the 'complex specificness' (Geertz, 1973, p. 26) of KT Edwards as a single case, where the 'effective story should be specific and circumstantial,' (Wolcott, 1995, p. 174). The 
single case enables a particular telling of Edwards' story as an instantiation of the emerging CEO position for both the individual and for the system. Adopting a microethnographic approach, we were concerned with 'the local and situated ecology' of Edwards' operations, (Garcez, 2017, p. 435). Four hour long semi-structured interviews took place, each with a key theme. The first centred on Edwards' career history (CHI), the second on values and beliefs (BPI), the third on MAT structure (STR), and the fourth on Edwards' localised networks (NWI). All interviews were recorded, transcribed and subjected to member checking (Lincoln and Guba, 1985). Informal unscripted discussions took place providing a rich source of data. Ten shadowing episodes comprising trailing Edwards on visits to schools and lessons, during duties, school tours, car journeys and seventeen more formal observations including open evenings, a staff recruitment morning and formal meetings (for example meetings with the executive team, business meetings, line management meetings) totalling over forty hours. These were recorded as fieldwork notes (FWN) either written in situ or immediately after.

Arendtian scholarship is helpful to support contemporary and historical thinking about the devastation of public-sector education, and so in reading Edwards' professional biography, we investigate how educational professionals position themselves through Arendt's (1997) characterisation of the parvenu and pariah. This is important because, for those living and working in new dark times, there is an imperative for people to assimilate, to conform, to 'continue to chatter and talk that drown[s] the reality of life in incomprehensible triviality,' (Berkowitz, 2010 p. 4), and in so doing the light is obscured.

For Arendt, seeking to understand the collapse of the public and private realms, there can be both hope and despair. For example, in her essay We Refugees, she writes of the rupture in refugees' lives and how, in attempting to forget, one denies oneself: 'the less we are free to decide who we are or to live as we like, the more we try to put up a 
front, to hide the facts and to play roles.' (Arendt, 2007, p. 270). In dark times, private optimism becomes despair as all boundaries between the public and private are destroyed, where the sense of loss is profound as, in attempting to assimilate, we lose what Arendt (1958) identifies as plurality in the sense of how we are each unique, and natality in how the fact of being born means we have the capacity to do new things. In explaining her thinking on loss and isolation, Arendt introduces and develops the concepts of pariah and parvenu. Originally, the idea emerged in Rahel Varhagen, Life of a Jewess, (1953) and in her essays, We Refugees (1943), and The Jew as Pariah (1947). In Rahel Varnhagen, Arendt sees Rahel's' life as a larger history of Jewish assimilation and alienation. Arendt writes of Rahel's 'inner life' and her yearning for acceptance, not least through establishing her salons in the late $18^{\text {th }}$ and early $19^{\text {th }}$ century - scenes of social neutrality where 'nothing really mattered but personality, and the uniqueness of character, talent, and expression' (Arendt, 2017, p. 76). Arendt's account explains Rahel's lifelong project in persuading society 'to accept her career as a parvenu,' (Arendt, 1997, p. 237). In her desire to assimilate, which Arendt saw as an 'aggressively active process,' (Bernstein, 1996, p.20), Rahel has to lie, 'erase' her friends, change her name, marry, and renounce her citizenship, in essence she lives a fraudulent life. Rahel's life is illusory as a parvenu - one who has recently arrived. The parvenu conforms to society through a life of obedience, 'vulgar banality', simulation and 'the abandonment of truth' (Arendt, 1997, p. 242). Conversely, the life of the pariah is the affirming of one's individual self yet is isolating because one's ability to act with others 'in the pursuit of common concern is destroyed.' (Arendt, 2017, p. 623). The pariah, then, embodies isolation and rupture from the public realm, labouring without action. Arendt rejects any form of historical determinism (Bernstein, 1996, p. 38): rather, the pariah and parvenu are separated out as 
'ideal human types,' (Arendt, 1997, p.276), but discussed relationally within a lived life rather than as a binary categorisation. We present a summary of each in Tables 1 and 2.

\section{INSERT TABLE 1 HERE}

Table 1: Arendt and the pariah (based on Arendt, 1997, 2007a; b)

Table 1 outlines five positions for the Pariah ideal type: this enables the researcher to read data in ways that focus on the individual's agency to determine identity and practice (e.g. conscious, poet), and that focus on the structuring of that agency through legal and social rules and conventions.

This interplay of agency and structure is also evident in the four positions of the Parvenu ideal type in Table 2, whereby the structuring of agency is a process of waiting, surrender and career, with the potential for regret and return through a form of realisation and judgement.

\section{INSERT TABLE 2 HERE}

\section{Table 2: Arendt and the parvenu (based on Arendt, 1997, 2007a; b)}

Tables 1 and 2 provide simplifications that veil the realities in which Arendt developed her insights into a lived life. Our data analysis follows our positioning as conscious pariahs, and so we attribute to Edwards the status of a former pariah who became a parvenu. His pariah identity is located in his original outsider-ness to the corporate world: his professional biography demonstrates that his career began and continued for a considerable time within and for public-services education. While accounts of educational professionals have demonstrated aspects of exclusionary pariah ideal types 
through their practice (e.g. Winkley, 2002) and through rendering themselves 'stateless' by leaving the profession (e.g. Thomson, 2009), our reading of the LLTP data is that Edwards was actually a parvenu in waiting. As an educational professional in a public system, he demonstrated and enacted corporate dispositions, and through the emerging MAT system he positioned as a parvenu abandonneur in surrendering his values and beliefs situated in public education, ultimately becoming a parvenu par excellence.

The parvenu abandonneur is a lived experience, where the person 'has to adapt his tastes, his life, his desires to attain these things' (Arendt, 1997, p. 241). As 'upstarts' (Arendt, 2007a, p. 274), parvenus are the pariah's counterparts. The parvenu has chosen freely, and by 'using his elbows' (Arendt, 2007b, p. 296) he 'is called to play the cast meticulously and exactly' (Arendt, 2007b, p. 279). The parvenu par excellence reaches beyond 'seeking' towards a fully self-deceptive life, abandoning his past, erasing connections, and so is characterised by an 'over-estimation of himself'. He creates and attains opportunities through visible social climbing - the Varnhagens were the creators of the Goethe cult in Berlin, with Goethe 'the friend of kings' (Arendt, 1997, p. 240) and the private rewards where 'being innocently liked is triumph for the parvenu' (Arendt, 1997, p. 241). It seems that for the parvenu par excellence, 'the smallest successes dazzle him with an illusory: everything is possible' (Arendt, 1997, p. 239), and this strengthens the sense of agency where he 'dare not be grateful because he owes everything to his own powers, he must not be considerate to others because he must esteem himself a kind of superman of efficiency, an especially good and strong and intelligent specimen of humanity a model to follow' (Arendt, 1997, p. 248). Our reading of the data recognises Edwards as a parvenu par excellence at a time when anyone who thinks or does things differently is a policy enemy (Hyman, 2005) through first, the presentation of the self in relation to elite private demands and processes; second, the negotiation of the self in ways 
that generate acceptance; third, the development of the self through networked social climbing; and fourth, the achievement by the self through acclaimed outcomes.

The parvenu positioning is precarious because the cost of attaining it is the abandonment of truth' (Arendt, 1997, p. 242), whereby denying the human condition of action, much remains in the dark. For Rahel, whilst annihilating her whole existence, she decides ultimately to rebel 'against such a condition' (Arendt, 1997, p. 245) and lives 'altogether inwardly' as a pariah. Whilst she achieved the 'virtuoso capacity for selfdeception' as a parvenu (Arendt, 1997, p. 246), she questioned if she could ever get away from 'what one truly is' thus as a parvenu she recognised the folly of her project. Indeed, in her later years, Rahel retains 'a passionate protest' to her parvenu-hood, since her previous life as pariah was freer. Ultimately, Rahel accepts her Jewishness, resisting her parvenu-hood, becoming a parvenu recogniser, and finally accepts her pariah status, concluding that her exercises in assimilation were merely 'cosmetic' (Arendt, 1997, p. 258). Our analysis considers the juxtaposition of first, Edwards' positioning as a parvenu par excellence, and second, how his practices suggest he is handling the conflicting identities as educational professional interplayed with corporate entrepreneur.

\section{Edwards as pariah in emergent new dark times}

Edwards entered a public education system as a school teacher with pro-private dispositions. Edwards' distinctive background is rooted in his family's business, where he worked hard and seized entrepreneurial opportunities:

Edwards: I came from a business family. When I was 12, I started working in my uncle's company, and worked for my dad on the markets. We used to buy women's clothes. We bought bootlace skirts, took them to [name of town] my brother and I, $£ 3.99$ they were. We didn’t give any pennies back in change and at the end of the day I did not know where to put the money. I think we came home with about two and half thousand pounds. 
Interviewer: How old were you then?

Edwards: Eighteen. We went the next week, the first ten people wanted their money back. We took about $£ 20$ because it was raining, we came home, But that's how it is... I worked for my uncle's stationery company. Every holiday he gave me a little van and in the summer, he went to Spain, I ran the company. (NWI, 17/4/18).

These private dispositions in a public profession suggest Edwards as an unconscious pariah in a public system. He established himself 'under existent conditions' (Arendt, 2007b, p. 294), playing the role of market trader, standing on the outside, excluded from the 'world of political realities,' (Arendt, 2007b, p. 276) whilst relishing the freedoms, 'comfortable protection' and independence of the family business. A teacher in the early 1980’s, Edwards enthusiastically undertook varied roles:

'I wasn't ambitious; I just did everything ... I ran the community venture we took over about $£ 100,000$. I wrote a bid for $£ 4$ million for the new tennis centre, so I was author of that, and I raised, I think about... £2million,' (CI, 26/9/17).

He used his business acumen to develop the school commercially through running the 'community venture'. He became deputy head 'in charge of the community,' head teacher in 1997 and executive head in 2007. The period saw the decline of the welfare state under Thatcherism with neoliberal practices encouraged in schools where business efficiency and effectiveness were key. The dismantling of local authorities in England was accelerated by the 1988 Education Reform Act, which increased the powers of the UK Secretary of State; devolved school resources from local authorities to head teachers; and increased competition through parental choice and the publication of school league tables. Rapid structural change continued with New Labour governments (1997-2010), which 
introduced the academies programme, where businesses and philanthropists sponsored poorly performing urban schools, rendering schools independent and but non-fee paying. This modernisation policy was based on New Public Management (NPM), drawn from private-sector management focusing on customer, enterprise, and outcomes (Gunter et al. 2016). The 'turbocharged' reforms (Gunter, 2012, p. 99) that defined the period saw the corporatisation of schools (Courtney, 2015a), with corporate practices, such as outsourcing and the use of consultants (Gunter and Mills, 2017), corporate language and the commodification of leadership training penetrating public education in the UK and internationally (Saltman, 2010). Against this backdrop, educational professionals, including Edwards, saw opportunities for advancement through the negotiation of self; 'adapting his life and desire' in undergoing nationally accredited leadership-training programmes; accepting government invitations to act in advisory roles; and seeking opportunities to extend reputations through school-to-school support (Gunter, 2016).

The new school structures created under New Labour accelerated after 2010 with the Coalition (2010-2015) and then Conservative governments (2015 onwards) where there now exist over seventy school types in England (Courtney, 2015b). Outside of local democratic control, centrally funded by the government, many are run by a plethora of businesses, faith organisations and private individuals, with many forming MATs. For Edwards as head of an 'outstanding' school, further opportunities to collaborate and federate continued: 'we then became in demand' culminating in the formation of the Lawrence Trust in 2012 with Edwards, adapting to his new circumstances became CEO in 2014. Edwards' yearning for assimilation into the corporate world of education services progressed with his labouring - developing his contacts: 'I spend a lot of time working with local councillors, key community leaders, people who make a difference.' Through his school-support work, he has 'improved the education standards across the 
region'. In so doing, Edwards enhanced his agency through successful take-overs and professional accreditation: he is a National Leader of Education, and using 'all his forces and talents' (Arendt, 1997, p. 239), has gained acceptance within privileged groups such as civil servants and ministers, 'I have presented to Number 10' and 'I had dinner with [name] the Secretary of State...' He has 'pedalled' (his term) the LT online resource at the House of Lords for example. Furthermore, Edwards has developed his connections with private sector business owners who sit on the LT board of trustees, enabling access to and the gradual assimilation into the corporatised world of non-education dark times.

As a conscious pariah in a public system, his biography shows that he was a parvenu in waiting adapting his early entrepreneurial career and applying it to his circumstances as a career professional. This reconceptualisation of his professional identity and his work in securing compliance to the vision as a CEO of a MAT has enabled him to assimilate as a parvenu par excellence.

\section{Edwards as parvenu in new dark times}

In becoming a parvenu par excellence, Edwards presents himself as a corporate leader fulfilling the corporate demands of his position as CEO. He has adapted his 'tastes,' 'life,' 'desires' (Arendt, 1997, p. 241) through his professional life as he is a non-executive director of a national charity - an offshoot of a PLC, chair of the board of a national funding foundation and a non-executive director in the public health sector. He also sits on the board of a regional business hub. He charges out his services as a consultant which now includes work internationally. As a parvenu par excellence he promulgates his methods for successful school take-overs at DfE networking events: 'we have a threestage plan - we think it takes 18 months, to get it into a [good] place...' Edwards secures the Trust vision and ultimately compliance to it, structuring the MAT as the corporation, 
with a back office, brand ambassador, operations director, an executive leadership team, designing and selling learning products for profit, adopting the rhetoric and language of the corporate parvenu. Part of his integration is assimilating 'to dominant trends' (Benhabid, 1996, p. 10) such as government policy on school take-overs:

We've got a really tight back office function; we have a growth strategy...we are fairly ruthless in saying "well if it doesn't benefit the trust why would we do it?" We need to gather assets. Assets mean people. We go into a place, often you've got some assets that then become the next school improvement people. Our best school improvement team are the ones who have been through the mill in a school that has not been very good, (BPI $5 / 12 / 17)$.

Moreover, the development of self is consolidated through networked social climbing: Edwards has used his isolation from professional associations by cultivating membership of non-educational networks. As 'socially neutral spaces' (Arendt, 1997, p. 112), Edwards' networks, fostered over time, offer important opportunities for resource exchanges; dialogue with the membership enhances his agency as a successful CEO. These spaces, like Rahel's salons of Berlin, have enabled Edwards' full assimilation into the corporate world, enabling the achievement by the self through acclaimed outcomes: these comprise increased agency, executive status through executive board membership, chairing a charitable foundation and recognition as an education expert and consultant: 'I am often called upon to speak to the media as the go-to person in education' (CI 26/9/17). As a parvenu par excellence, he is the 'model...to follow,' (Arendt, 1997, p. 248) and is expected to lead others to become parvenus to forget what used to be in order 'to acquiesce to everything' (Arendt, 1997, p. 245). This is partially achieved through his leadership of the MAT, where 'everything is scripted' and where 'there is no alternative but obedience,' (Arendt, 1997, p. 237), and where those who do not conform are disposed of: 
...we've instigated a dashboard which at a glance we can see where people are at any one time... we have the same standards across the Trust that's my job and the Executive Team's job to keep the standards. (BPI 5/12/17).

Edwards as a careerist has progressed to become a parvenu par excellence, an 'upstart'; his arrival 'fools everyone'; he performs as his own master, identifying with those he is mixing with: however, 'the parvenu can achieve no stable realistic sense of his own power' (Pitkin, 1998, p. 25). The position is volatile: 'the smallest successes are hard won,' (Arendt, 1997, p. 239). Such dynamics are fast moving, instinctive even, and certainly open to new possibilities, and following Arendt (1997), we need to consider what the trends suggest about the security of his embodied incorporation.

\section{Edwards as parvenu par excellence}

As a parvenu, Edwards' pariah-hood of being biographically located in a public-sector job has become regularised and recognised as advantageous to how his current privatised job is legitimised. Claims to be in public education while making private gains can be convincing when spoken and enacted by someone from a public-education background. He demonstrates the advantages secured from isolated forgetting but is also a role model for those who remember and need savvy advice from someone with expertise located in parvenu-hood. As CEO, he has cemented his parvenu status with his full assimilation to the corporate non-education dark times. Much of Edwards' activities remain in the dark: he enjoys great discretion; accountability is imprecise; membership of his networks is opaque and fluid; and he is politically astute (Hughes, 2019, p. 8). His pariah status has been reworked through his parvenu activities as a modern and modernising headteacher. With the corporate interventions in public services, Edwards seized the opportunities such reforms offered. However, 'parvenu-hood' is precarious because: '...you forget because part of why people want you sometimes is because of who you are' (NWI, 17/4/18). He 
admits he changes his identity depending on where he is, wearing a different name badge depicting his changed role - a symbol of his 'parvenu-hood' when: '...identity is changed so frequently that nobody can find out who we actually are' (Arendt, 2007a, p. 270). Does Edwards think about what he is doing? He is certainly providing some business illumination as a CEO. Whilst Edwards is constructing his agency through his 'parvenuhood', being structured by government policy to be a parvenu, he is mindful of this position: 'well I might not agree with policy, so I have to be careful,' (NWI, 17/4/18). There are glimpses when reading the data that he disagrees with increased government centralisation where remnants of the previous public system remains in modernised public bureaucracies (e.g. the role of the Local Headteacher Board and the Regional School Commissioner who decide on school takeovers) '...they are not great for us...' (STI, 11/9/18) he says owing to slow decision-making. The state is investing in MATs as the preferred organisational arrangement for school-place provision, but to achieve this, CEOs must accept schools into their MAT. However, such a move reminds Edwards of what he is seeking to forget, and his position is a reminder of the frustrations of bureaucratic interference that heads invoked to support the first wave of school-autonomy reforms from 1988 (see Downes, 1988). Consequently, he is resigned to sometimes being powerless:

I said to Ofsted last week, that basically do what you want because the types of schools we've got, we are going to get battered anyway so we'll just accept it... (STR 11/9/18).

However, he uses the validity of isolation from the state by recognising that localised market forces play out to his advantage as 'our parents aren't bothered: they will still rock up as the kids do' (STR 11/9/18). These tensions matter, where Edwards is mindful that the constant spotlight on the MAT performance by regulatory bodies, 
increased consumerism, and public accountability, 'the DfE wants results, results will always win,' (STR 11/9/18). and so the parvenu is imperilled.

Edwards is recognising that his parvenu-hood is threatened by the continued involvement of government in the provision and regulation of public-services education, not least because he has to address issues (e.g. provision of school places for all children) that he thought he had left behind. To this end, he has led reforms as a National Leader of Education by visiting, talking and enacting the success of isolated leadership. However, he has also left his head teacher role to pursue noneducational interests such as being a board member of a local charity and chair of a national foundation. He has extended his entrepreneurial activities in undertaking a lucrative overseas commission. He has 'pulled back' from government-sponsored initiatives to survive as a parvenu par excellence. It seems that the remaining tensions mean that Edwards is an embedded but precarious parvenu (Arendt, 1997, p. 258) finding that parvenu-hood 'did not guarantee reality'; his labouring as CEO could be a superficial, decorative activity. In Arendtian terms, 'freedom and equality are not going to be conjured into existence by individuals' capturing them by fraud as privileges for themselves' (Arendt, 1997, p. 258). Consequently, the self-deception is incomplete; the past is remembered through how 'public provision' or 'a public system' requires a relational form of freedom that jeopardises the security of Edward's parvenu-hood. However, the resilience of his economised-self from his early years means that he continues to 'forge' public education through integrating the market trader with the school-place provider. Convinced of his status as parvenu par excellence as CEO, he has assimilated fully: 'I'm not going to stop, it's just great now.' (NWI, 17/4/18). Edwards has constructed his own darkness as part of the system and ultimately escaped into dark times. 


\section{Discussion}

We argue that the constructed interplay of the pariah and parvenu to understand leader, leading and leadership are useful to help the field think in new ways about how professionals in the top job in and across schools have exercised their agency to break with a welfarist past and to persist in enacting paradigm-shifting changes, where these reforms have been shown not only to fail in their objectives of raising standards for all, but to constitute newly dark times in how they enable segregation, hierarchisation and human disposability. Where a pariah leader desires parvenu status, we suggest that the collateral damage to public education, professional lives and identities is particularly extensive. This insight offers an alternative perspective to previous analyses, where education reforms have been understood as a teleological project in themselves or as the result of key actors' capital accumulation, rather than as a by-product of their identity work.

In other words, Courtney's (2017b) account of the consequences of MAT CEO dominance depicted it as motivated by an arbitrary susceptibility to the desire for power mediated by high original status. Here, however, we account more fully for the singular, blinkered and determined ways in which MAT CEOs' agency may dismantle public provision while aiming primarily to identify more convincingly with the discursively privileged construction of the corporatised CEO. This is revealed in the quotidian, government-promoted collocations of MAT leadership with business: the launch event of the academy-focused Confederation of School Trusts, for example, featured a keynote speech by the then Education Secretary Damian Hinds and the announcement of a new partnership with the Confederation of British Industry, whose head of education and skills noted that 'A lot of issues that multi 
academy trusts are dealing with are issues businesses have dealt with for decades' (Cope, in Robertson, 2018, para. 15). The message is clear that business should provide the template for MAT leaders' activities and identities.

In making these arguments, we note that not all will feel the pull of parvenuhood, and so the concept helps explain differences in approach to the MAT CEO role. The literatures are replete with examples of pariah leaders who did not seek parvenuhood, including 'Dave' and 'John' in Thomson (2009) and 'Les' in Courtney (2017a); as well as examples of what we retrospectively identify as parvenus, who have renounced their roots in a public, welfarist system to perform a particularly intense form of corporatism (see e.g. Courtney and Gunter, 2015; Gunter and McGinity, 2014), often born of a desire to belong and a concomitant recognition that they do not. In this sense, being parvenu is homologous to being lower-middle class, in that one may try rather too hard in one's efforts to 'pass' as authentic, whether it be as middle class or edu-preneur. The trappings of authenticity, like items of luxury, are taken for and read as substantive rather than understood as proxies, or even as mere distracting baubles (Gunter et al. 2017).

However, the stakes are considerably higher than simply being a question for the individual leader of 'passing' or not: parvenus unthinkingly destroy human bonds and identities as well as notions of public education, through their parvenu striving and, in their justifications to assimilate. The border between the 'parvenu par excellence' and that of the 'recogniser' signifies the moment for the parvenu recogniser to 'think about what [they] are doing' (Arendt, 1958 p. 5). What is it that prevents this emergence from dark times? In Arendt's Eichmann in Jerusalem (1963), Eichmann justifies his role in arranging the mass deportation of Jews to extermination camps as straightforward: he was thoughtlessly following orders without question. 
As a careerist, he was dependable and diligent in seeking personal advancement, remaining remote from reality through a failure of judgement. Eichmann 'had done nothing... since when has it been a crime to carry out orders? Since when it has been a virtue to rebel?' (Arendt, 1994, p. 127). The conditions in which Edwards operates as parvenu par excellence appear ordinary; he advances his career through cooperation and assimilation 'as an agent of change: playing a key role in the modernising of schooling' (Gunter, 2014, p. 94). However, the modernisation project results in 'integrated isolationism' (Gunter, 2014, p. 52) of the parvenu par excellence in thinking that they belong but in reality, remain isolated.

\section{Conclusion}

In examining the distinctive nature of the current darkness in non-educational times we have used Edwards' story to illuminate Edwards' parvenu-hood, where as a pariah located in a public-education system, he yearned to become a parvenu in ways that are now corporatised. The collapse of the public into the private has pitched us into darkness and normalised non-educational times. Edwards' assimilation into the private world of parvenu-hood has entailed him presenting, negotiating, developing the self through selfexposure. He has done this through integrating a corporate identity and praxis. The proactive, but jumbled collapse of the public-education system has forced the creation of depoliticised private arenas where Edwards (along with others) resides, and 'where there is only injustice only and no indignation' (Brecht, 2019, p.736). Arendt calls on those in the public realm to think about what we are doing and to shed light onto these new dark times: instead of 'walking calmly across the street' (Brecht, 2019, p. 734), we have sought to illuminate the challenges we face as thinkers and researchers. We recognise the challenges faced by social scientists in using conceptual tools to 'think with data' about 
professional practice as leadership (e.g. Courtney et al. 2018), where in Arendtian terms we are in effect 'conscious pariahs', where we seek not to 'put our confidence into old verities or even new truths' (Arendt 1993, p. 111) but to draw education in non-education dark times into the light of the political realm. In addition, we are mindful that using Arendtian scholarship developed in distinctive mid-to-late twentieth century dark times we are following her methodology of seeking to understand the world as it is now through our data and as such make a contribution to the utility of such thinking (Gunter 2014, 2018b). We are hopeful that 'the presence of others who see what we are seeing and hear what we hear assures us of the reality of the world and ourselves' (Arendt, 1958, p.50). In examining Edwards' story as 'conscious pariahs', we recognise the CEO role as a symbol of new dark times and reject others' actions in dark times who 'accept the calm freedoms of the pariah... [and] retreat into quiet corners...preserving the illusion of liberty and unchallenged humanity' (Arendt, 2007b, p. 296). Through the data we understand the realities of the stories where in truth, CEOs like Edwards repudiate their past, forgetting who they once were, instead they are superordinated, embodying aloof and isolated success. In forgetting, they break from their history and professional knowledge. Edwards remembers public education, for he participates in government policy through his school collaborations and take-overs, and he is required to remember his trader background to do his job as CEO. This enhances his agency, but he resists becoming fully involved and thus retreats to parvenu-hood par excellence. The CEO role is not a fixed blueprint; rather, those inhabiting it are creating a role where they are making active choices about what to remember and what to forget.

\section{References}

Appadurai, A. (2017) Democracy fatigue. In: H. Geiselberger, (Ed) The Great Regression (Cambridge: Polity) 1-12. 
Arendt, H. (1958) The Human Condition. Second Edition (Chicago: The University of Chicago Press).

Arendt, H. (1963) Eichmann in Jerusalem: A Report on the Banality of Evil (London: Penguin).

Arendt, H. (1993) Men in Dark Times. (San Diego: A Harcourt Brace \& Company).

Arendt, H. (1994) Essays in Understanding 1930-1954. (New York: Schocken Books)

Arendt, H. (1997) Rahel Varnhagen, The Life of a Jewess. (London: John Hopkins).

Arendt, H. (2007a) We refugees. In The Jewish Writings, (New York: Schocken), 264274

Arendt, H. (2007b) The Jew as Pariah. In The Jewish Writings, (New York: Schocken) 275-297.

Arendt, H. (2013) The Last Interview and other Conversations. (Brooklyn, NY: Melville House Publishing).

Arendt, H. (2017) The Origins of Totalitarianism. (London: Penguin).

Arrowsmith, R. (2001) A right performance. In: Gleeson, D. and Husbands, C. (Eds.)

The Performing School. (London: RoutledgeFalmer), 33-43.

Astle, J. and Ryan, C. (eds) (2008) Academies and the Future of State Education.

(London: CentreForum).

$\mathrm{Au}, \mathrm{W}$. and Ferrare, J.J. (Eds) (2015) Mapping Corporate Education Reform. (New

York, NY: Routledge).

Beckett, F. (2007) The Great City Academy Fraud. (London: Continuum).

Benhabid, S. (1996) The reluctant modernism of Hannah Arendt. (London: Sage).

Berkowtiz, R. (2010) Introduction. In R. Berkowitz, J. Katz, and T. Keenan (Eds.)

Thinking in Dark Times: Hannah Arendt on Ethics and Politics, (New York: Fordham University), 3-14. Retrieved from:

http://www.jstor.org.manchester.idm.oclc.org/stable/j.ctt13wzz8c

Bernstein R.J. (1996) Hannah Arendt and the Jewish Question. (Cambridge: Polity Press).

Bourdieu, P. (1990). The Logic of Practice. (Cambridge: Polity Press).

Brecht, B. (2019) The Collected Poems of Bertolt Brecht. Translated from the German and edited by T. Kuhn, T. and D. Constantine (New York: Liveright Publishing).

Callahan, R.W. (1962) Education and the cult of efficiency. (Chicago: The University of Chicago Press).

Clark, P. (1998) Back from the Brink. (London: Metro Books).

Courtney, S.J. (2015a) Corporatised leadership in English schools, Journal of Educational Administration and History, 47 (3), 214-231.

Courtney, S. J. (2015b) Mapping School types in England. Oxford review of Education 41 (9) $799-818$.

Courtney, S.J. (2017a) Corporatising School Leadership through hysteresis. British Journal of Sociology of Education, 38 (7), 1054-1067.

Courtney, S.J., McGinity, R., and Gunter, H.M. (eds) (2018) Educational Leadership, Theorising Professional Practice in Neoliberal Times. (Abingdon: Routledge) 
Courtney, S.J. (2017b). The courtier's empire: A case study of providers and provision. In: H.M. Gunter, H.M., D. Hall, and M.W. Apple (Eds.), Corporate elites and the reform of public education, (Bristol: Policy Press), 177-189.

Courtney, S.J., and Gunter, H.M. (2015). Get off my bus! School leaders, vision work and the elimination of teachers. International Journal of Leadership in Education, 18 (4), 395-417.

Daniels, D. (2011) From reality to vision: the 'birth' of The Petchey Academy in Hackney. In: H.M. Gunter, (Ed) The State and Education Policy. (London: Continuum). Downes, P. (1988) Local Financial Management in Schools. (London: Nelson Thornes Limited).

Garcez, P. (2017) Micro-ethnography in the Classroom, in Hronberger, N.H. (Ed.), Encyclopaedia of language and education. (Boston: Springer) 257-271.

Geertz, C. (1973) The interpretation of cultures. (New York: Basic Books).

Gewirtz, S. (2002) The Managerial School. (London: Routledge).

Goddard, V. (2014) The Best Job in the World. (Carmarthen: Independent Thinking Press).

Gorski, P.C., and Zenkov, K. (2014) (Eds.). The big lies of school reform: Finding better solutions for the future of public education. (New York, NY: Routledge).

Grace, G. (1995) School leadership. (London: Falmer Press).

Guggenheim, D. (2010) Waiting for superman. Documentary.

https://documentarylovers.com/film/waiting-for-superman/

Gunter, H.M. (2018a) Depoliticisation and education policy. In: J. Wilkinson, R. Niesche, and S. Eacott, (Eds) Dismantling public education: Implications for educational leadership, policy, and social justice. (London: Routledge).

Gunter, H.M. (2018b) The Politics of Public Education. (Bristol: Policy Press).

Gunter, H.M. (2016) An intellectual History of School Leadership Practice and Research. (London: Bloomsbury).

Gunter, H. M. (2014) Education Leadership and Hannah Arendt. (Abingdon: Routledge).

Gunter, H.M. (2012) Leadership and the Reform of Education. (Bristol: Policy Press) Gunter, H.M. and Forrester, G. (2010) Education Reform and School Leadership. In: S. Brookes, and K. Grint (Eds) The Public Sector Leadership Challenge. (London: Palgrave), 54-69.

Gunter, H.M. and Hall, D. (2013) Public trust and education. In: S. Llewellyn, S. Brookes, and A. Mahon, (Eds) Trust and Confidence in Government and Public Services. (Abingdon: Routledge), 204-220.

Gunter, H.M., Courtney, S.J., McGinity, R., and Hall, D., (2017). School principals in neoliberal times: a case of luxury leadership? In: K. Saltman, and A. Means (Eds.), Handbook of Global Education Reform. (Hoboken NJ: Wiley-Blackwell).

Gunter, H.M. and Mills, C. (2017) Consultants and consultancy: the case of education. (Cham Switzerland: Springer).

Gunter, H.M., Grimaldi, E., Hall, D., and Serpieri, R. (eds) (2016) New Public Management and the reform of Education: European Lessons for Policy and Practice. London: Routledge. 
Gunter, H.M. and McGinity, R. (2014) The politics of the academies programme: natality and pluralism in education policy making. Research Papers in Education 29 (3) 300-314.

Hughes, B.C. (2019) Investigating the CEO of a MAT: examining the practices and positions on 'the street.' Educational Management Administration and Leadership. Available at: https://journals.sagepub.com/doi/abs/10.1177/1741143219833688?journalCode=ema d. (Accessed March 2019)

Hyman, P. (2005) One Out Of Ten, From Downing Street Vision to Classroom Reality. (London: Vintage).

Kulz, C. (2017) Factories for Learning. (Manchester: University Press).

Lincoln, Y., and Guba, E. (1985) Naturalistic enquiry. (Beverley Hills: Sage).

Mansell, W. (2018 March 12). Sky-high pay in education isn't just for university bosses. Look at academies. The Guardian [online].

https://www.theguardian.com/commentisfree/2018/mar/12/high-pay-educationuniversity-bosses-leaders-academy-trusts [Accessed 24 March 2019].

McInerny, L. (2018 June 19). The academy dream is in freefall. Schools should not have to pick up the pieces. The Guardian [online],

https://www.theguardian.com/education/2018/jun/19/academy-schools-collapseexecutive-pay-assets (Accessed 24 March 2019).

Newman, J. and Clarke, J. (2009) Publics, Politics and Power. London: Sage.

Pitkin, H.F. (1998) The attack of the blob Hannah Arendt's concept of the social.

Chicago: (Chicago University press).

Ravitch, D. (2014) Reign of Error. (New York, NY: Vintage Books).

Ribbins, P. (ed.) (1997) Leaders and Leadership in the School, College and University (London: Cassell).

Ribbins, P. and Sherratt, B. (1999) Managing the Secondary School in the 1990s: a new view of Headship. In: M. Strain, B. Dennison, J. Ouston, and V. Hall (Eds)

Policy, Leadership and Professional Knowledge in Education. (London: PCP), 183194.

Robertson, A. Hinds wants school leaders' ideas to improve MAT assessment. Available at: https://schoolsweek.co.uk/hinds-wants-school-leaders-ideas-toimprove-mat-assessment/ [Accessed 29 August 2019].

Ryan, C. (2008) The history of academies. In: J. Astle, and C. Ryan (Eds) Academies and the Future of State Education. (London: CentreForum), 1-12.

Salokangas, M., and Ainscow, M. (2018) Inside the Autonomous School, making sense of a global educational trend. (London: Routledge).

Saltman, K. J. (2010) The Gift of Education: public education and venture philanthropy. (New York, NY: Palgrave Macmillan).

Saltman, K.J. and Gabbard, D.A. (2003) Education as Enforcement. New York: Routledge.

Southworth, G. (1995) Looking into Primary Headship. (London: The Falmer Press). Stanford, P. (2007 January 25) Headteacher: the job no one wants. 
https://www.independent.co.uk/news/education/education-news/head-teacher-the-jobno-one-wants-433507.html

(Accessed $1^{\text {st }}$ April 2019).

Sugrue, C. (ed) (2005) Passionate Principalship, Learning from the Life Histories of School Leaders. (Abingdon: RoutledgeFalmer).

Thomson, P., (2009) School leadership: Heads on the block? (Abingdon: Routledge).

Turner, C. (2018 May 5) Almost a third of headteachers now leave within three years, official data shows.

https://www.telegraph.co.uk/education/2018/05/05/almost-third-headteachers-nowleave-within-three-years-official/ (Accessed $1^{\text {st }}$ April 2019).

Weale, S. (2018 June 26). 300 schools picked out in GCSE 'off-rolling' investigation. The Guardian [online], https://www.theguardian.com/education/2018/jun/26/300-schools-picked-out-in-gcseoff-rolling-investigation (Accessed 24 March 2019).

Winkley, D. (2002) Handsworth Revolution, The Odyssey of a School. (London: Giles de la Mare Publishers Limited).

Wolcott, H.F. (1995) The Art of Fieldwork. (Walnut Creek, Ca: Altamira).

Wolcott, H.F. (1973) The Man in the Principal's Office. (Walnut Creek, Ca: Altamira).

\section{TABLE 1}

Table 1: Arendt and the pariah (based on Arendt 1997, 2007a; b)

\begin{tabular}{|l|l|}
\hline Pariah as... & Distinctive positioning \\
\hline Conscious & A rebel who actively rejects assimilation and takes action. \\
\hline Unconscious & A social outcast with no desire to be embraced within society. \\
\hline Poet & Withdraws into the private realms of art, imagination. \\
\hline Refugee & A stateless nonentity, always under suspicion and detached. \\
\hline Nobody & $\begin{array}{l}\text { A superfluous nobody working to become the same as others but } \\
\text { is always dismissed. }\end{array}$ \\
\hline
\end{tabular}

TABLE 2

Table 2: Arendt and the parvenu (based on Arendt 1997, 2007a; b)

\begin{tabular}{|l|l|}
\hline Parvenu as... & Distinctive positioning \\
\hline Waiting & Seeing “parvenu-hood" through grateful acquiescence \\
\hline
\end{tabular}




\begin{tabular}{|l|l|}
\hline Abandonneur & Surrenders identity and seeks full assimilation \\
\hline Par Excellence & $\begin{array}{l}\text { Career parvenu who uses all talents to live a self-deceptive } \\
\text { life }\end{array}$ \\
\hline Recogniser & Rejects self-deception, and struggles to relocate as pariah \\
\hline
\end{tabular}

